\title{
What Is Aging?
}

\author{
Beatrix Grubeck-Loebenstein \\ Institute for Biomedical Aging Research, Austrian Academy of Sciences, Innsbruck, Austria
}

With 2012 being the European Year for Active Aging, many initiatives are drawing public awareness to the importance of aging research (gerontology). Aging research is interdisciplinary as it concerns many different fields such as biology, medicine, social sciences, product design and technologies, as well as demography. Biogerontology aims at understanding the biological mechanisms of molecular, cellular, organ, and organismic aging.

Current concepts of aging, in particular aging in higher organisms such as mammals, perceive cellular senescence as a key process contributing to aging of tissues and the entire organism. Starting from the initial observation by Leonard Hayflick that normal human cells have a limited replicative capacity [1], in the last 5 decades molecular mechanisms driving cellular senescence have been established, based primarily on experiments with cultured cells. Senescent cells have been identified in vivo in mammalian tissues, including tissues from mice, non-human primates, and humans. However, the mechanisms underlying cellular senescence in vivo and the functional significance of senescent cells are poorly understood. The clearance of age-associated damage plays an important role in determining lifespan. This is particularly well documented for molecular damage at the subcellular level, including repair of nucleic acids, repair of certain protein modifications, and the turnover of damaged proteins. In addition, recent data suggest that clearance of damaged organelles by autophagy is another mechanism assuring longevity [2]. There is good evidence linking repair mechanisms, for example DNA repair, to lifespan regulation in many species including humans, as best exemplified by premature aging syndromes such as Werner syndrome caused by mutations of DNA repair enzymes [3]. Much less is known about mechanisms that control the abundance of senescent cells in mammalian tissues; in particular, mechanisms by which damaged cells are removed are poorly understood. According to recent evidence, the clearance of p16Ink4a-positive senescent cells delays agingassociated disorders in mice indicating that cellular senes- cence is causally implicated in generating age-related phenotypes, and that removal of senescent cells can prevent or delay tissue dysfunction and extend health span [4]. There is also evidence that components of the innate immune system contribute to the clearance of senescent cells in certain human tissues [5]; however, the significance of innate and adaptive immune responses for the clearance of senescent or damaged cells in aging tissues remains to be investigated.

Interestingly, the immune system itself is strongly affected by the aging process, as the involution of the thymus starts early in life and is nearly complete between the age of 40 and 50 (fig. 1) [6]. With thymic involution, the output of naïve $\mathrm{T}$ cells decreases, and antigen-experienced cells - senescent cells among them - accumulate. Senescent T cells have an effector phenotype and have been shown to be pro-inflammatory and cytotoxic. They have short telomeres and do not proliferate well [7]. Due to a decreased DNA damage response, they are sensitized to apoptotic cell death [8]. They can still survive in the presence of IL-15, a cytokine which is produced in large amounts by the aged bone marrow $[9,10]$. IL-15 as well as IFN- $\gamma$ have also been discussed as suppressors of erythropoiesis [11]. It seems possible that low erythropoiesis in old age may at least in part be explained by the overproduction of both cytokines in the bone marrow niche.

As biological aging is known to represent a predisposing factor for the development and progression of age-related diseases $[12,13]$, it seems of utmost importance to find intervention strategies to prevent or at least postpone aging and its pathological consequences. A key mechanism of postponing age-associated damage is caloric restriction which has been shown to extend the lifespan in rodents and the healthspan in non-human primates [14]. Effects of caloric restriction on human health are well documented; however, so far it is not clear whether caloric restriction has the potential to extend human lifespan. Although caloric restriction is a well accepted paradigm with regard to extending lifespan, molecular mechanisms by which caloric restriction contributes to lifespan ex-

\section{KARGER}

Fax +497614520714

Information@Karger.de

www.karger.com (c) 2012 S. Karger GmbH, Freiburg

$1660-3796 / 12 / 0395-0299 \$ 38.00 / 0$

Accessible online at:

www.karger.com/tmh
Prof. Dr. Beatrix Grubeck-Loebenstein

Director, Institute for Biomedical Aging Research

Austrian Academy of Sciences

Rennweg 10, 6020 Innsbruck, Austria

Tel. +43 512 583919-0, Fax -8

Beatrix.Grubeck@oeaw.ac.at 


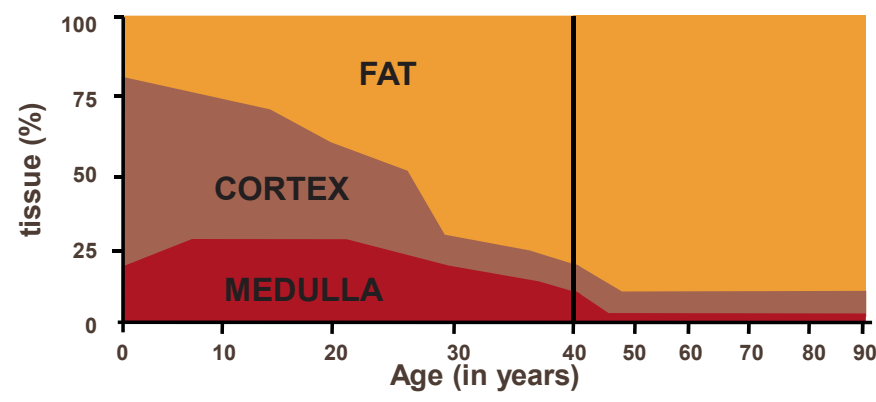

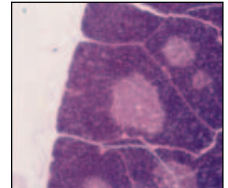

5 years

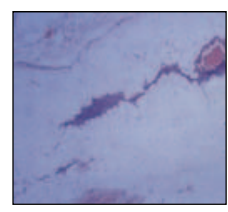

70 years
Fig. 1. Aging of the immune system. A Thymic involution. B Modified from Immunol Today 17, George AJ and Ritter MA, Thymic involution with aging: obsolescence or good housekeeping?, pp. 267-272, 1996, with permission of Elsevier.'

tension are not completely understood. There are reports from lower eukaryotic model organisms suggesting the involvement of various distinct pathways in lifespan extension by caloric restriction; however, this question is not resolved for any mammalian system. In the past, many attempts have been made to extend lifespan and healthspan by pharmacological and/or nutritional interventions. Based on the assumptions of the
'Free Radical Theory of Aging', large projects on supplementation of antioxidants were conducted; however, no beneficial effects of general antioxidant supplementation on age-associated diseases could be observed [15]. In addition, there is emerging evidence that reactive oxygen species can trigger beneficial signaling responses that prolong lifespan. More recently, small molecule-based interventions have been developed with the aim to extend lifespan/healthspan by targeting molecular pathways known to contribute to longevity. In this respect, lifespan extension by several of these treatments was reported in model organisms up to the level of fruit flies. One of these compounds, resveratrol, which is believed to target and activate sirtuins, was shown in long-term experiments in mice to improve health parameters under high-calorie diet conditions, but had no effect on lifespan under standard conditions [16]. More recently, feeding of mice with rapamycin, an antagonist of the TOR pathway, was shown to extend lifespan [17]. Furthermore, another paradigm was established based on the observation that feeding model organisms with spermidine increases lifespan through elevating the rate of autophagy [2].

The described measures and therapeutic approaches will hopefully enable as many people as possible to grow old in good health. Considering the demographic changes presently taking place in the whole of Europe, one realizes that it is not only a desirable goal for individuals to stay independent and mobile as long as possible, but that it is becoming increasingly important to relieve society of the enormous economic burden of age-related diseases, hospitalization, and long-term care.

\section{References}

1 Hayflick L, Moorhead PS: The serial cultivation of human diploid cell strains. Exp Cell Res 1961;25: 585-621.

$>2$ Eisenberg T, Knauer H, Schauer A, Buttner S, Ruckenstuhl C, Carmona-Gutierrez D, Ring J, Schroeder S, Magnes C, Antonacci L, Fussi H, Deszcz L, Hartl R, Schraml E, Criollo A, Megalou E, Weiskopf D, Laun P, Heeren G, Breitenbach M, Grubeck-Loebenstein B, Herker E, Fahrenkrog B, Frohlich KU, Sinner F, Tavernarakis N, Minois N, Kroemer G, Madeo F: Induction of autophagy by spermidine promotes longevity. Nat Cell Biol 2009;11:1305-1314.

$>3$ Huang S, Lee L, Hanson NB, Lenaerts C, Hoehn $\mathrm{H}$, Poot M, Rubin CD, Chen DF, Yang CC, Juch H, Dorn T, Spiegel R, Oral EA, Abid M, Battisti C, Lucci-Cordisco E, Neri G, Steed EH, Kidd A, Isley W, Showalter D, Vittone JL, Konstantinow A, Ring J, Meyer P, Wenger SL, von Herbay A, Wollina U, Schuelke M, Huizenga CR, Leistritz DF, Martin GM, Mian IS, Oshima J: The spectrum of WRN mutations in Werner syndrome patients. Hum Mutat 2006;27:558-567.

4 Baker DJ, Wijshake T, Tchkonia T, LeBrasseur NK, Childs BG, van de Sluis B, Kirkland JL, van Deursen JM: Clearance of p16Ink4a-positive senescent cells delays ageing-associated disorders. Nature 2011;479:232-236.

5 Krizhanovsky V, Xue W, Zender L, Yon M, Hernando E, Lowe SW: Implications of cellular senescence in tissue damage response, tumor suppression, and stem cell biology. Cold Spring Harb Symp Quant Biol 2008;73:513-522.
6 George AJ, Ritter MA: Thymic involution with ageing: obsolescence or good housekeeping? Immunol Today 1996;17:267-272.

7 Arnold CR, Wolf J, Brunner S, Herndler-Brandstetter D, Grubeck-Loebenstein B: Gain and loss of T cell subsets in old age--age-related reshaping of the T cell repertoire. J Clin Immunol 2011;31:137-146.

$>8$ Brunner S, Herndler-Brandstetter D, Arnold CR, Wiegers GJ, Villunger A, Hackl M, Grillari J, Moreno-Villanueva M, Burkle A, Grubeck-Loebenstein B: Upregulation of miR-24 is associated with a decreased DNA damage response upon etoposide treatment in highly differentiated CD8(+) T cells sensitizing them to apoptotic cell death. Aging Cell 2012;11:579-587.

9 Herndler-Brandstetter D, Landgraf K, Jenewein B, Tzankov A, Brunauer R, Brunner S, Parson W, Kloss F, Gassner R, Lepperdinger G, GrubeckLoebenstein B: Human bone marrow hosts polyfunctional memory CD4+ and CD8+ T cells with close contact to IL-15-producing cells. J Immunol 2011;186:6965-6971.

10 Herndler-Brandstetter D, Landgraf K, Tzankov A, Jenewein B, Brunauer R, Laschober GT, Parson W, Kloss F, Gassner R, Lepperdinger G, GrubeckLoebenstein B: The impact of aging on memory $\mathrm{T}$ cell phenotype and function in the human bone marrow. J Leukoc Biol 2012;91:197-205.

11 Mullarky IK, Szaba FM, Kummer LW, Wilhelm LB, Parent MA, Johnson LL, Smiley ST: Gamma interferon suppresses erythropoiesis via interleukin-15. Infect Immun 2007;75:2630-2633.
12 Gavazzi G, Krause KH: Ageing and infection. Lancet Infect Dis 2002;2:659-666.

13 Wick G, Jansen-Durr P, Berger P, Blasko I, Grubeck-Loebenstein B: Diseases of aging. Vaccine 2000;18:1567-1583.

14 Fontana L, Partridge L, Longo VD: Extending healthy life span - rom yeast to humans. Science 2010;328:321-326.

15 Sesso HD, Buring JE, Christen WG, Kurth T, Belanger $\mathrm{C}$, MacFadyen J, Bubes V, Manson JE, Glynn RJ, Gaziano JM: Vitamins E and C in the prevention of cardiovascular disease in men: the Physicians' Health Study II randomized controlled trial. JAMA 2008;300:2123-2133.

16 Baur JA, Pearson KJ, Price NL, Jamieson HA, Lerin C, Kalra A, Prabhu VV, Allard JS, LopezLluch G, Lewis K, Pistell PJ, Poosala S, Becker KG, Boss O, Gwinn D, Wang M, Ramaswamy S, Fishbein KW, Spencer RG, Lakatta EG, Le Couteur D, Shaw RJ, Navas P, Puigserver P, Ingram DK, de Cabo R, Sinclair DA: Resveratrol improves health and survival of mice on a high-calorie diet. Nature 2006;444:337-342.

17 Harrison DE, Strong R, Sharp ZD, Nelson JF, Astle CM, Flurkey K, Nadon NL, Wilkinson JE, Frenkel K, Carter CS, Pahor M, Javors MA, Fernandez E, Miller RA: Rapamycin fed late in life extends lifespan in genetically heterogeneous mice. Nature 2009;460:392-395. 